\title{
Fraud Detection and Audit Expectation Gap:
}

\section{Empirical Evidence from Iranian Bankers}

\author{
Mahdi Salehi (Corresponding author) \\ $\mathrm{PhD}$, Assistant Professor, Zanjan University, Zanjan, Iran \\ D.N. 1, Nagilo Alley, Hidaj City, Zanjan Provenance, Iran \\ E-mail: Mahdi_salehi54@yahoo.com
}

Zhila Azary

Research Staff, Ministry of Agriculture, Zanjan Branch, Zanjan, Iran.

D.N. 194 Shahed 2 Street, 22 Bahman High way, Zanjan City, Zanjan Province, Iran

\begin{abstract}
Our focus in this study is to determine the expectation gap in auditor's responsibility between auditors and bankers in Iran. In the view of fact, the key factor in enhanced credibility is the perception of stakeholders that the external auditors judge to financial statements providing through the management. In recent years corporate scandals were happened, so third parties demand auditors should be as an honest judge. Third parties expect the auditors should have more responsibility to detect fraud. The auditors although they view their role as bringing credibility to financial statements, know because of scope want limitation of their responsibility cannot detect all kinds of fraud. Therefore there is so called gap. Our findings indicate that there is significant gap between auditors and bankers in areas of auditor's responsibilities to detection fraud and illegal acts. In this study, the authors came to conclusion that the bankers have reasonableness expectation gap from auditors.
\end{abstract}

Keywords: Auditor, Responsibility, Fraud Detection, Audit Expectation Gap

\section{Introduction}

As we inter new millennium, the recipients of financial statements have become a far sophisticated and informed group. The demand more from an audit function than a mere attestation with regard to auditor responsibility still be account for, furthermore during the last years, there has been a great number of accounting scandals throughout the world; most recent among then are; Enron, WorldCom, Parlmalat, and Famie Mac. These scandals have seriously damaged the confidence in financial reporting, because of fraud. After these huge number of scandals had profound impact on the profession, leading to the disbanding of the Public Oversight Board (Mulligan, 2002) and the collapse of Arthur Andersen, one of the world" largest accounting firms (Bayer). New legislation (e.g. Sarbanes --Oxley Act of 2002) and a new oversight board are just a few of the effects of these scandals.

The primary responsibility of an auditor is to verify whether the financial statements exhibit a true and fair view of state of affair of the business and their secondary responsibility is the prevention and detection of errors and frauds. The primary responsibility for the prevention and detection of fraud and error rests with both those charged with governance and the management of an entity in spite of the fact that financial statements are the representations of the management. While discharging their duties in accomplishing these two audit objectives, there are also other responsibilities that emerge for the auditors to perform.

Fraud involves misallocation of resources or distorted reporting of the availability of resources, so this contradicts the elements of round and prudent management. In addition, these failures have focused attention on auditors' ability and incentives to detect management fraud. Audit failures arising from management fraud are largely responsible for efforts by regulators, legislators and accountants themselves, to require the accounting profession to accept more responsibility for evaluating and reporting on clients' and internal controls. Although the third party emphasize that auditor must be detect of kinds of fraud, the auditors thinking in other ways; they believe that is not their duty the detect fraud; so, there is a gap, between auditors and third parties.

Our objective in this study is to determine expectation gap between auditors and bankers in Iran. For achieving this goal, we do a survey study based on questionnaire. In the first section, we deal with the history of auditing in Iran. Second section deals with dimensions of fraud. In third section the literature review is presented. In forth section, we deal with 
methodology and finally we present results obtain and conclusion in the fifth section.

\section{History of Auditing in Iran}

Pursuant to the Islamic revolution of Iran in 1979, according to a bill ratified by thep Revolutionary Council, many enterprises were confiscated or became under direct supervision of Government. To audit and perform statutory examination of these enterprises, three audit firms were established in the public sector, i.e., Nationalized Industries and Plan Organization Audit Firm 1980, Mostazafan Foundation Audit Firm 1981, Shahed Audit Firm 1983.

In 1983 an act was ratified by the Parliament, to merge and embody these three audit firms together with Audit Company (established in 1971 to audit government corporations) to establish Audit Organization. Audit Organization's by-laws was also approved by the Parliament in 1987 and the Organization established as a legal entity, with financial independence affiliated to the Ministry of Economic Affairs and Finance to follow those audit firms functions and pursue the activities legislated in the Organization's Act and by-laws.

Audit Organization's by-laws were revised and approved by the Council of Ministers in 2003 to comply with the Article 4 of the Third Economic, Social and Cultural Development Plan and the Organization's legal status changed to State Owned Limited Company.

\subsection{Objectives}

The Organization's main objectives are:

To provide government with basic needs in the field of auditing and specialized financial services for state owned and government supervised entities;

To set Accounting and Auditing Standards and Professional Ethics in compliance with Islamic Rules as well; and

Research in scientific and practical methods of accounting to enhance accountancy compatible with country's needs.

\subsubsection{Auditing Standards - Due Process}

Due process of Auditing Standard is as following:

Deciding on a subject for research. The Auditing Standard Setting Committee decides on the topics to be considered by Standard Setting Development.

Preliminary studies. After deciding on the subject, necessary research and studies are commenced by the Advisors of Standard Setting Department. In this phase, the standards of other countries like USA, UK, Australia and Canada, International Auditing Standards, research carried out in relation to the subject, accounting practice in Iran and the law and all issues relating to the subject are recognized, collected and studied. The result of this phase is presentation of study reports.

Deciding on necessity of a standard development. The Standard Setting Committee decides on the necessity of development of a standard based on the result of preliminary studies.

Preparation of primary draft. If the Auditing Standard Setting Committee requires the standard development, the advisory group prepares a primary draft based on study reports, after field studies and some meetings with professionals and constituents. One of the main policies of Auditing Standard development is compliance with International Auditing Standards. Therefore, concerning the subject on which there is an International Auditing Standard, this International Auditing Standard is used as the main basis for the standard development. The outcome of this phase is the primary standard draft.

Development of standard draft. In this phase, the Auditing Standard Setting Committee presents the final standard draft, after deep and broad reviews and necessary amendments. The outcome of this phase is the standard draft.

Public comment. For public comment, any standard draft is made available to the public by different ways like publishing in professional journals, Internet (Organization Site), etc. Also, according to the subject nature, the standard draft is separately sent to some authorities.

The opinions received in respect of the standard draft is concluded and presented to the Auditing Standard Setting Committee by the Standard Setting Department. The Committee amends, if necessary, the standard draft and after approval by the Technical Committee, the revised standard draft is presented to the Board of Executive of the Organization.

Ultimate approval, the final statement will be published when the Board of Executive and Board of Governor of the Organization approve the final text of the standard. The board reviews the Auditing Standard and after possible amendments approves and sends them to the Board of Governor of the Organization for the ultimate approval. After approval by the Board of Governor, the final text of the Auditing standard is published and becomes operative. 


\section{Insert chart 1}

\subsection{Association of Certified Public Accountants (IACPA)}

By formation of Accounting Organization in 1987, the case of auditing the accounts of companies and financial institutions, founding professional accountancy system, the how of formation and limits of nongovernmental audit practices had been left undetermined? To satisfy this need, 'the Act of enjoying the specialized and professional services of recognized accountants as Certified Accountants' was passed through the Majlis (Islamic Consultative Assembly) in 1993. This act authorized the government to financially monitor production, commercial and service corporations and make sure that their financial statements were reliable and correct enough to maintain public interests. In 1995, 'Regulation of Assessing Certified Accountants' Competence and Selecting them, was approved by the Cabinet, and subsequently a committee to assess the Certified Accountants' competency was set up and introduced by the Minister of Finance and Economy.

In early 1996, upon enforcing the regulation of assessing the Certified Accountants' competence, the Ministry of Finance and Economy assigned a mission of ten members, seven of whom were from the assessing group and three from other accountants, as the first Certified Accountants to produce a comprehensive statute and introduce it to the Cabinet for approval in a six month period. This statute was produced in the due time, and in September 1999 it was handed in to the Cabinet.

\section{The dimensions of fraud}

Most of the research concerning fraud focused on so-called red flags which are defined as conditions that indicate potential fraud by management or others, with deliberate skills; Furthermore, several frauds reported in the last few decades have led to impair audit practice and audit financial statements.

Fraud, as it is currently defined in accounting standards, reports "an intentional act that results in a material misstatement in financial statements that are the subject of an audit" (AICPA, 2003). There are two ways in which a material misstatement could occur with respect to fraud: misappropriation of assets and fraudulent financial reporting. Misappropriation of assets, as the name suggests, refers to the theft of company assets that may result in the company's financial statements being materiality misstated (AICPA, 2003). According to IFAC (1977) fraud may involve:

Misappropriation of assets;

Suppression or omission of the effect of transactions from records or documents;

Recording of transactions without substance, and

Misapplication of accounting policy.

According to prosser (1971) the elements of fraud as follows:

False representation of a material fact; and

Representation made with knowledge of its falsity.

According to an editorial of Fortune (1978) reported that increased time pressure has led independent auditors to do shopping in their audits. Out of 1,100 practitioners, 58 percent had indicated that they had signed off on a required audit step without completing the work or noting the omission. However, the absence of controls neither constitutes a material weakness in the accounting system, nor in auditing practice great frauds. In such cases management fraud may occurs that damaged company's financial management as well as audit practice. According to Kapnick (1980), management fraud stems from improper actions of management normally accompanied by false documentation of transactions or with holding of relevant information, resulting in a material impact on the financial statements and in financial detriment to shareholders a person acts in the representation; and the person acting is damaged by his or her reliance. According the Elliot and Willingham (1980), financial fraud is the deliberate fraud, committed by management that injures investors and creditors through materiality misleading financial statements. According to Flesher (1996), fraud means dishonesty in the form of intentional deceptions or a willful misrepresentation of fact.

Albrecht (1996) states every fraud consists of three elements:

(1) Theft act, which involves taking cash, inventory, information, or other assets manually, by computer, or by telephone.

(2) Concealment which involves the steps taken by the perpetrators the hide the fraud from others; and

(3) Conversion, which involves selling or converting stolen assets into cash and then spending the cash.

According to Ramos (2003), fraud may occur because of three main resources namely: incentive, opportunity and, rationalization.

Insert chart 2 
(I) Incentive/pressure: in this position management or other employees may have an incentive or be under pressure, which provides a motivation to commit fraud as follows:

1-Business pressures:

To reach budgets, meet targets;

Maintain status as high flier in organization;

To prop up failing ventures or weak contracts; and

To get new funding.

2-Personal pressures:

Financial problems or extravagant life style; and

Drug or gambling habits-greed-not wanting to admit to problems.

(II) Opportunity: circumstances exist, for example, the absence of controls, ineffective controls, or the ability of management to override controls that provide an opportunity for fraud to be perpetrated and some other position listed below:

Decentralization or reorganization of companies;

High volume of major transactions;

New and complex productions;

Access to credit;

No real deterrent;

Little chance of discovery; and

Grey areas in the rules.

(III) Rational/Attitude: those involved in a fraud are able to rationalize a fraudulent act as being consistent with their personal code of ethics. Some individuals possess as attitude, character or set of ethical values that allows them to knowingly and intentionally commit a dishonest act such as:

Management don't care;

Everyone else doing it;

No-one gets hurt;

I am only taking what is due to me;

Insurance will pay; and

Only borrowing.

Ramos (2003) listed the following examples of management fraud and their underlying reasons:

- Misappropriation of assets;

- Reporting inflated assets values on operating results so that those perpetrating the fraud can retain their positions;

- Increasing their remuneration;

- Improper use of assets to the benefit of management;

- Enhancing the holding of company stock;

- Over statement of assets or under statement of liabilities to present a favorable financial position or results of operations;

- The siphoning off the assets through transactions with affiliated entities;

- Kickbacks and other irregular transactions between officers and outside parties; and

- Lack of disclosure of significant information

Sawyer (1988) believes that three conditions under which fraud exists are attributed to the environment set by management.

(1) Situational pressures experienced by employees of enterprise;

(2) Uncontrolled access to assets, coupled with managements indifference; and

(3) Personal trait undermining personal integrity. 
He lists eight reasons behind management fraud:

(1) Executives sometimes take rash stops from which they cannot retreat;

(2) Profit centers may distort facts he held off divestment;

(3) Incompetent managers may deceive in order to survive;

(4) Performance may be distorted to warrant large bonuses;

(5) The need to succeed can turn manager to deception;

(6) Unscrupulous managers serve interests which conflict;

(7) Profits may be inflated to obtain advantages in the market place; and

(8) The one who controls both the assets and their records in a perfect position to falsify the records.

\section{Fraud and audit expectation gap: some empirical evidences}

A critical issue relating to auditor responsibility lies in defining as auditor's obligation to detect and report frauds or irregularities committed by clients' employees or management (Lys and Watts, 1994).

In general, the purpose of the audit practice is to enable them to express an opinion whether the accounts presented, show a true and fair view. Therefore, the object of an audit is to ensure that the accounts on which the auditor is reporting show a true and fair view and are not misleading. The general public appears to have a high expectation that auditors will detect or prevent all frauds, in other words, third parties believe that auditors must assume a responsibility beyond examining and attesting the fairness of financial statements and shoulder a direct obligation to protect the interest of the audit beneficiary through detecting and reporting frauds as irregularities (Sikka et al, 1992).

In the view of the fact, third parties desire external auditor who to able to certify as to the accuracy of the accounts presented, so in this condition they want that the object of an audit may be said as follows:

(1) The detection of fraud;

(2) The detection of technical errors; and

(3) The detection of errors of principle.

In short, third parties are thinking without fraud detection there is no use in audit practice whereas; the auditing profession believes its responsibilities are limited to planning the audit so that there is a reasonable expectation of detecting material fraud. However, the auditors are litigating that the, detect of fraud is neither economical nor the duty of auditors whereas, the other party looking for absolute assurance in audit practice,

therefore there arise so-called expectation gap. The expectation gap is the difference between what users of financial statements, the general public perceives an audit to be and what the audit profession claim is expected of them in conducting an audit (Ojo, 2006). The general public appears to have a high expectation that auditors will detect or prevent all fraud, whereas the auditing profession does not agree fraud detection as primary audit objective. Thus there is an expectation gap whereby the general public believes that the auditor should be responsible for attempting to detect all fraud. In the view of the fact, the frequent scandals were made to the biggest component of the audit expectation gap being auditors' perceived incapacity to detect fraud and warned impending corporate collapses. The fraud expectation gap refers to the publics' expectation that auditors will detect fraud, and report on if it exists, whereas auditors do not accept that they have a primary responsibility to detect fraud. So far, several studies became to the conclusions that the auditors should be blamed for not meeting users' expectations. Although the auditors had been asked to detect errors or frauds (Brief, 1975), the profession's refusal of performing the fraud detection duties had fueled the expectation gap (Hooks, 1992). The professionals still, attempting to avoid fraud detection responsibility to protect their self-interest.

\section{Review of literature}

In recent years academics and professionals have focused on expectation gap especially regarding the effect of fraud on expectation gap. The main function of audit expectation gap is to detect fraud (Salehi and Nanjegowda, 2006). According to Baron et al. (1977) who conducted a questionnaire survey in the US to elicit views within the financial community on two major issues;

(1) The auditor's responsibilities for detecting corporate irregularities and illegal acts; and

(2) The auditor's responsibility for disclosing irregularities and illegal acts. The results revealed that auditors and other parties (financial analysts, bankers, and managers) have significantly different believes and preference on the extent of auditors' responsibilities for detecting and disclosing irregularities and illegal acts. In particular, users held auditors to be more responsible for detecting and disclosing irregularities and illegal acts than the auditors believed themselves to be. Lowe and Pany (1993) surveyed 141 members of a municipal court juror's pool and 78 auditors from a large international accounting firm to assess their attitude toward the auditing profession. The result of the study reveals an 
expectation gap. The jurors view the auditors' role as that of a public watchdog or guardian to the extent of expecting the auditor to actively research out the smallest fraud. Auditors disagree with this characterization of their task.

Epstein and Geiger (1994) conducted a survey of stock investors that revealed a startling evidence of the expectation gap between the assurances auditors provided the financial statements compiled by management and the expectation of investors and other users of financial statements. Over 70 per cent of the 246 investors surveyed believe that auditors should be held responsible for detecting material misstatements due to fraud, and some 47 percent expect auditors to provide absolute assurance the financial statements contain no material misstatement due to errors. In the UK, Humphrey et al (1993) examined the expectation gap by ascertaining the perception of individuals of audit expectations issues through the use of a questionnaire. The issues investigated including the following questions. What is and should be the role of the auditor? What should be the prohibitions and regulations placed an audit firms? And what decisions could auditors be expected to make? The respondents included chartered accountants, corporate finance directors, investment analysts, bank lending officers, and financial journalists. The survey revealed significant difference between auditors and the respondents in their views on the nature of auditing. The results confirmed that an audit expectation gap exists, specifically in areas such as the nature of the audit action and the perceived performance of auditors. The critical components of the expectation gap were found to include auditors' fraud detection role and the extent of auditors' responsibilities to third parties.

McInnes (1994) reviewed Gloeck and Jayer's (1993) study on the audit expectation gap in the Republic of South Africa and found three areas namely, independence of auditors, role of auditors relating to fraud and going concern issues in which an expectation gap exists between auditors and non-auditors.

Low (1984) conducted a survey amongst auditors and analysts in Singapore and in Australia revealed that in both countries, significant differences in perceptions were found in areas regarding the extent of assurance over fraud detection and the reliability of information presented in audited financial statements. Another survey conducted by Low et al (1988), who surveyed a sample of auditors and financial analysts in Singapore regarding their perception of objectives of company audits. Participants were provided with a list of 13 potential objectives. Significant differences and expectation gaps were found in the areas of fraud prevention, guaranteeing the accuracy of financial information, effective utilization by the company of government grants, levies and subsidies, and management. A study by Best et al (2001) sought to determine the level and nature of the expectation gap in various areas of auditor responsibility. They gather information through the questionnaire and participants were auditors, bankers, and investors. Their results indicated a wider expectation gap in the areas of the auditor's responsibility for preventing and detecting fraud, maintenance of accounting records, and selection of appropriate auditing procedures. MC Enroe and Martens (2001) surveyed public accountants and individual investors to determine the extent to which the expectation gap exists for various facets of the attest function found investors have higher expectations than auditors in the areas of disclosure, internal control, fraud and illegal operations. Another survey carried out by MC Enroe and Martens (2002) by comparing audit partners' and investors' perceptions of auditors' responsibilities involving various dimensions of the attest function. The results revealed that an expectation gap currently exists: investors have higher expectations for various facts and assurances of the audit than do auditors in the following areas: disclosure, internal control, fraud, and illegal acts. It was also found that investor expect auditors to act as public watchdog. Koh and Woo (2001) investigated the audit expectation gap between auditors and management and found a significant gap, which management expecting more that auditors in the areas of preventing and detecting fraud, illegal acts, errors, and in guaranteeing the accuracy of financial reports. Study conducted by Fadzly and Ahmad (2004) regarding several dimensions of expectation gap in Malaysia. Questionnaire instrument were used for information collecting and participants were auditors, bankers, brokers, and investors. The results revealed evidence of expectation gap in Malaysia from the viewpoint of auditors and other participants, particularly on issues of concerning auditor's responsibilities. A wide gap was found regarding auditor's responsibilities in fraud detection and prevention, preparation of financial statements and accounting records. The gap was also found with regard to auditor's scope of legal responsibility in a fraud related business failure. More recent survey conducted by Alleyne and Howard (2005), between auditor and users around the responsibility of auditor for fraud detection through interview in Barbados. The results revealed that there is a wide expectation gap between auditors and users for fraud detection. The auditors strongly disagreed that they were responsible for uncovering fraud compared to the users' strong view that they should be responsible.

A survey conducted by Beelde et al. (2005) relating to audit expectation gap in Belgium. Participants were auditors, bankers, and managers. The results revealed that there are significant differences between auditors and other parties in several fields such as going concern, auditor role, and auditing process, liability of auditors to third parties, and fraud detection and prevention. In addition results revealed that there is an expectation gap with regard to the attributes detecting and preventing errors'. $89 \%$ of the auditors were convinced that they are good at detecting errors, but only $78 \%$ of the managers and $62 \%$ of the bankers agree with this. $63 \%$ of the auditors were of the opinion that auditors are of the opinion that they are good at preventing errors, but it must be emphasized that some $5 \%$ of the auditors are of the opinion that this is not revealed. $44 \%$ of the managers believed that auditors were good at this, $26 \%$ believed that they 
achieved an average result and $29 \%$ was of the opinion that they wer0065 bad at it. Only $1 \%$ was of the opinion that this is not part of the job responsibilities of an auditor. The results by the bankers are as follows: $29 \%$ good, $22 \%$ average, $42 \%$ bad, and $7 \%$ not relevant.

In recent years few researches conducted related to auditing practice in Iran, which in this area it seemed more researches should be conduct.

A questioner survey carried out by Nikkhah-Azad and Mojtahedzadeh,(1999) regarding to auditors responsibilities in Iran,which results reveled that the third parties emphasizing the auditors should be responsible on areas of detection of fraud, detection of illegal acts and responsibility to reporting overriding of regulation.

A questionnaire survey carried out by Hassas-Yeganeh and Khaleghi (2004) in Iran regarding attest function of independent auditors, between auditors and investors which the results showed that there is expectation gap between auditors and users on the attestation role of independent auditors. The results showed that there are significant differences between auditors and users regarding to reliability of audited financial statements, and also significant differences between auditors and users regarding to comparability of audited financial statements. Users believed that if the audited financial statements re-audited by others it will show different picture

\section{Methodology}

Since our main objective in this study is to test whether there is significant expectation gap between auditors and bankers in business environmental of Iran, so for accurate answer to this question, we design and develop a questionnaire based on method used in Chowdhury et al (2005),Fadzly and Ahmad(2004), and Best et al. (2001). The questionnaire used in the study includes two sections. The first section consist demographic information of the respondents and five statements about importance of auditing and financial reports. The second section includes 13 statements on the fraud and audit responsibilities regarding to illegal acts. The statements number 2, 3,7,12 and 13 are related to fraud and statements number 1, 4,5,6,8,9,10 and 11 are related to illegal acts. The measure instrument of the statements is a five-point likert type scale anchored "strongly disagree" (1) and "strongly agree" (5).

To test for the significant expectation gap between the parties of respondent, we employ Mann-Whitney U test. The test is chosen because it is especially valuable in dealing with ordinal data.

\section{Results}

In this section, the authors report the empirical findings of the statistical analysis for the auditor responsibility and audit expectation gap. For this purpose, 227 questioners from auditors and 261 questioners from bankers were collected in Tehran on the date of 2006. The all-statistical analyses were performed with the SPSS package software.

\subsection{Demographics of respondent groups}

The tables 1, shows that from 227 auditors are $78 \%$ graduate, $21 \%$ master, and almost $1 \% \mathrm{PhD}$ qualification, whereas from 261 bankers $90 \%$ have graduate, and 10\% master qualification. According to this table, the auditors have higher auditing and accounting education than bankers.

\section{Insert table 1}

With regard to Table 2, 98\% auditors and almost $60 \%$ bankers passed auditing courses. Also $100 \%$ auditors have accounting and auditing experience, while as the table shows 55\% bankers have accounting and auditing experience.

\section{Insert table 2}

\subsection{Results from belief of respondent groups}

Table 3 shows some information regarding to audit importance between auditors and bankers, which according to this Table $80 \%$ auditors strongly agree with importance of reading auditing report, while almost $50 \%$ bankers have same believe.

\section{Insert table 3}

According to this table from the viewpoint of bankers, audit report has less importance, reather than financial statement. Responds to the second question of this table support this claim that banker's has less attention to audit report. According to third question of the table, from the view point of bankers and auditors, both have higher believe the financial statements are very important, in other words $82.5 \%$ auditors and $69 \%$ bankers strongly agree that the financial statements are very important.

According to statements 4 and 5 revealed that auditors and bankers both strongly believe to importance of company and director profiles. This table shows almost $79 \%$ auditors and $77 \%$ bankers strongly agree with the importance of company profile, $73.6 \%$ auditors and $79 \%$ bankers strongly agree that director profile is very important.

Analysis of thirteen questions about auditors' responsibilities is shown in the table 4, which in this table for each groups as well as question analyzed Mean, Median and Std. Dev. This table revealed results of statistical analyses they are as 
follows:

\section{Insert table 4}

According to statement No.1, the Table shows that there is a significant difference between auditors and bankers. According to the table $\mathrm{V}, 79 \%$ auditors believes that the auditors do not have major role in producing financial statements, whereas just $12 \%$ bankers have same believe. In the other words more than $82 \%$ bankers strongly agree that auditors should play more roles in producing of financial statements. Statement No.2 and 3 revealed there is a significant difference between auditors and bankers, which according to table $\mathrm{V}, 70 \%$ auditors disagree to prevention and detection fraud and errors whereas, $70 \%$ bankers strongly agree that the auditors are responsible to presentation as well as detection of fraud.

Statements No.4 analyses of this statement revealed that there is a significant difference between auditor and bankers, which $61 \%$ auditors disagree with this statements, while $19 \%$ bankers disagree with this statement. In other words the auditors believe that the conducting of $100 \%$ examination in audit procedure nor economical neither feasible.

Statement No.5 result revealed that there is a significant difference between auditors and bankers which $87 \%$ auditors strongly agree, while $61 \%$ bankers agree with this statement.

Statement No.6, as indicates in the table, there is a significant difference between two parties. In other words $40 \%$ auditors and $66 \%$ bankers agree with certifying accuracy of financial reports.

Statement No.7 indicates that there is a significant difference between two parties. The result shows that $55 \%$ auditors disagree with this statement. Furthermore $66 \%$ bankers agree with this statement.

Statement No.8 reveals that 53\% auditors disagree with effectiveness of internal control on audit quality, while $67 \%$ bankers strongly agree with this statement; therefore there is a significant difference from the viewpoint of auditors and bankers.

Statement No.9: The result of Table 4 shows that there is no significant difference between auditors and bankers, mainly $83 \%$ auditors and $72 \%$ bankers strongly believe that the managers are responsible to maintaining accounting records.

Statement No. 10 shows that there is a significant difference between auditors and bankers, in other words $54 \%$ auditors disagree with safeguarding the assets of the company; whereas $69 \%$ bankers strongly agree with the statement, furthermore just $15 \%$ bankers disagree with statement.

Statement No.11: As a Table 5 shows that there is a significant difference between two groups, which result shows $83 \%$ auditors agree on detecting illegal acts by the management, while $67 \%$ bankers agree with this statement.

Statement No.12: as result shows regarding reporting all detected frauds and thefts to the relevant authority, there is no significant difference between two parties based on table IV. With regard to table V, $82 \%$ auditors and $71 \%$ bankers have a same idea regarding to the Statement No.12. In other words both parties strongly believe that the auditor should and must report all fraud and thefts detected to all relevant authority.

Statement No.13: As it shows in table 4, there is a significant difference between tow parties, which according to Table $\mathrm{V}, 55 \%$ auditors disagree with this statement, while just $20 \%$ bankers disagree with this statement, by the way $38 \%$ auditors and $64 \%$ bankers agree with that the auditor is responsible for detecting any deliberate distortion of financial information.

\section{Conclusion}

The main objective of this study is to find out empirical evidence of expectation gap between auditors and bankers in business environmental of Iran. For this propose, we did a survey study based on questioner. The findings indicate that there is deeply expectation gap between auditors and bankers. The results show that bankers are unawares of auditing functions. Firstly, they expect that auditors should play more roles in producing the financial statements. Secondly, the bankers believe seriously that prevention and detection of fraud is a part of auditor's responsibilities. Moreover the bankers are willing to accept more responsibility of detecting illegal acts by the auditors than by the management. Thirdly, the auditors don't lie on internal control while they are conducting auditing practices because in Iran internal auditors in any company work directly under the top manager, so the internal auditors don't have adequate independence. Finally, although auditors and bankers have deferent belief as mention above, the findings indicate that they have same expectation on areas of maintaining accounting records by management, reporting all detected fraud and illegal acts to authority by auditors.

The authors came to conclusion in the study that the bankers have reasonableness expectations from auditors, in other words, the Iranian auditors practicing according the Iranian regulation and they have limit responsibility to detection fraud and illegal acts.

For reducing such a gap, more communication is needed between auditors and third parties, mainly the bankers. Since the bankers are unawares a bout auditor responsibilities as well as limitation, if auditors have more and better 
communication with own third parties it will be reduce such a gap.

\section{References}

Albrecht, W.S. (1996). Employee Fraud, Internal Auditor, October, p: 26.

Alleyne, P and Howard, M. (2005). An Exploratory Study of Auditors' Responsibility for Fraud Detection In Barbados. Managerial Auditing Journal, Vol.20, No.3, pp: 284-303.

American Institute of Certified Public Accountants (AICPA). (2003). Consideration of Fraud In Financial Statement Audit. Statement On Auditing Standards No.82, New York.

Baron, C.D, Johnson, D.A, Searfoss, D.G and Smith, C.H. (1997). Uncovering Corporate Irregularities: Are Closing The Expectation Gap"? Journal of Accountancy, Vol.144, October, pp: 243-250.

Bayer, J. A. (2002). Fall From Grace: Joe Berardino Presided Over The Biggest Accounting Scandals Ever And The Demise Of a Begendary Firm. Here's What Happened. Business Week 3795(August12), p. 50.

Beelde, D.I, Cooper, S and Leydens, H. (2005). Expectations Of users Of Financial Information With Regard To The task Carried Out By Auditor", available at: www.Feb.ugent.be/fac/research/WP/Paper/WP_99_75.pdf-22No2005

Best P.J, Buckby, S and Tan, C. (2001). Evidence Of The Expectation Gap In Singapore. Managerial Auditing Journal, Vol.16, No.3 pp: 134-144.

Brief, R.P. (1975).The Accountant's Responsibility in Historical Perspective. The Accounting Review, April, pp:285-297.

Chowdhury,R ,Jnnes, J and Kouhy, R.(2005). The Public Sector Audit Expectation Gap in Bangladesh. Managerial Auditing Journal.Vol.20,No.8,pp:893-908.

Elliot, R.K and Willingham J.G. (1980). Management Fraud: Detection and Deterrence, Petrocelli Book New York.

Epstein .M J and Geiger, M. A. (1994). Investor Views of Audit Assurance: Recent Evidence Of The Expectation Gap. Journal of Accountancy, Vol.177, January, pp: 60-66.

Fadzly, N.M and Ahmad, Z. (2004).Audit Expectation Gap: The Case Of Malaysia. Managerial Auditing Journal, Vol.19, No.7, pp897-915.

Flesher, D.L (1996). Internal Auditing-Standards and Practices, The Institute Of Internal Auditors, Altamonte Springs, FL.

Foutune. (1978). Editoral, July, Vol.17, p: 95.

Gloeck J D and Jager, H. (1993). The Audit Expectation Gap in The Republic Of South Africa. Working Paper, School of Accountancy, University Of Pretoria.

Hassas-Yeganeh, Y and Khaleghi, A. (2004).The Expectation Gap Of Independent Audit Attest Function, Between Auditors And Their Report Users. The Iranian Accounting and Auditing Review ,Vol.11,No.35,pp:29-44.

Hooks, K.L (1992). Professionalism and Self-Interest: a Critical View of The Expectation Gap. critical Perspectives of CPA Practices, The CPA Correspondence in China, No.6, pp: 24-30.

Humphry, C G, Moizer, P and Turley W.S. (1993). The Audit Expectation Gap In Britain: An Empirical Investigation. Accounting and Business Research, Vol.23, Summer, pp: 395-411.

International Federation Of Accountants Committee (IFAC). (1997). Handbook, Technical Pronouncement. US

Kapnick, H. (1980). Responsibility And Detection in Management Fraud, Reading and Cases in Auditing, Dame Publications, Houston, TX.

Koh, H and Woo, E. (2001). The Auditor-Manager Expectation Gap in Auditing. Managerial Auditing Journal, Vol.16, pp: 176-188.

Low A M, Foo S and Koh, H C. (1988). The Expectation Gap Between Financial Analysts And Auditors: Some Empirical Evidence. Singapore Accountant, Vol.4, May, pp: 10-13.

Low, AM (1984). The Audit Report: Time for a Change? Singapore Accountant, pp: 17-21.

Lowe, D.J and Pany, K (1993). Expectation of the Audit Function. CPA Journal, Vol.63, August, p: 58.

Lys, T and Watts, R.L (1994). Lawsuits against Auditors. Journal of Accounting Research, Vol.32, pp: 65-93.

MC Enroe, J E and Martens, S.C. (2002). Taxman, March, Vol.9, pp: 236-251.

Mc Enroe, J.E and Martens S.C. (2001). Auditor's And Investor's Perception of the Expectation Gap. Accounting Horizons, Vol.15, No.4, pp: 345-358. 
Mc Innes, W M. (1994). The Audit Expectation Gap in The Republic Of South Africa. Accounting and Business Research, Vol.24, Summer, pp: 282-283.

Mulligan, T.S. (2002). Accounting Watchdog Reiterates it will Disband. Los Angeles Times, February.C4.

Nikkhah-Azad,A and Mojtahedzadeh,V.(1999). An empirical Examination Of Users' Perceptions Of The Independent Auditor's Areas Of Responsibilities With Respect To Financial Statements : A Comparative Study. The Iranian Accounting And Auditing Review,Vol.7, No.27, pp:1-70.

Ojo, M. (2006). Eliminating the Audit Expectation Gap: Reality or Myth? Available at: http://mpra.ub.uni-muenchen.de/232/.

Prosser, W.L. (1971). Hand Book of The Law of Torts, West Publishing, ST Paul MN.

Romas, M. (2003). Auditor Responsibility for Fraud Detection. Journal of Accountancy, January, pp: 28-36.

Salehi, M and Nanjegowda, K. (2006). Audit Expectation Gap: The Concept. Journal of Audit Practice, Vol.3, No.4, pp: 69-73.

Sawyer, L.B. (1988). Internal Auditing, The Institute of Internal Auditors, Altamonte Springs. FL.

Sikka, P Puxty, T Willmott, H and Cooper, C. (1992). Eliminating the Expectation Gap, London: ACCA.

Chart 1: Auditing Standards - Due Process
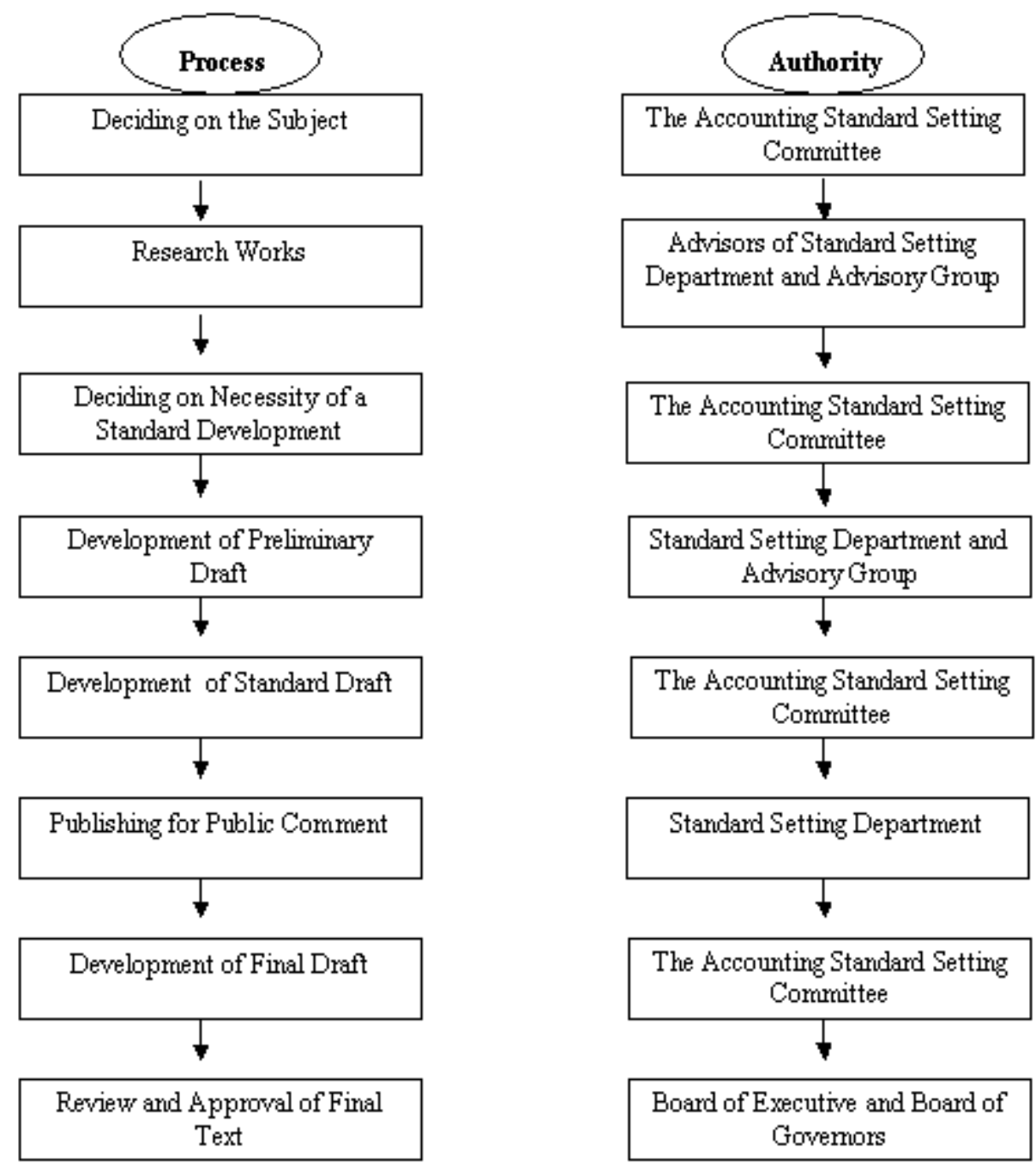
Chart 2: resources of fraud

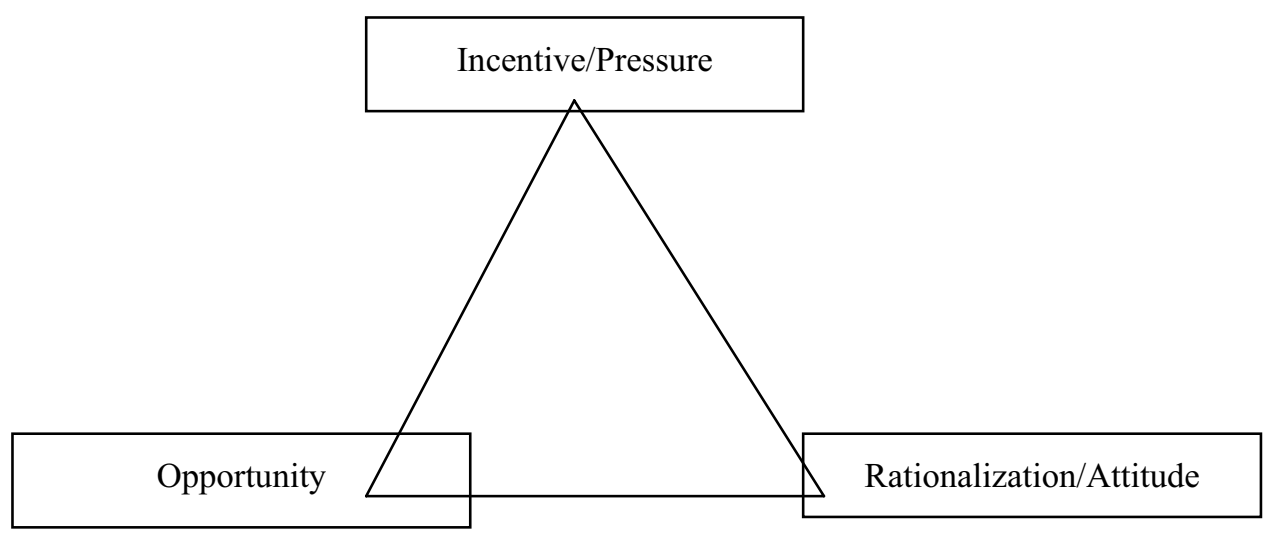

Source Ramos (2003)

Table 1. Respondent qualification

\begin{tabular}{|l|l|l|l|l|}
\hline \multirow{2}{*}{ Qualification } & Auditors & \multicolumn{2}{l|}{ Bankers } \\
\cline { 2 - 5 } & Frequency & Percent & Frequency & Percent \\
\hline Graduated & 178 & 78 & 236 & 90 \\
\hline Master & 47 & 21 & 25 & 10 \\
\hline PH.D & 2 & 1 & 0 & 0 \\
\hline Total & 227 & 100 & 261 & 100 \\
\hline
\end{tabular}

Table 2. Auditing and accounting knowledge

\begin{tabular}{|l|l|l|l|l|}
\hline \multirow{2}{*}{ Auditing and accounting knowledge } & Auditors & \multicolumn{2}{l|}{ Bankers } \\
\cline { 2 - 5 } & Yes & No & Yes & No \\
\hline Auditing Study & $98 \%$ & $2 \%$ & $60 \%$ & $40 \%$ \\
\hline Auditing \& Accounting Experience & $100 \%$ & $0 \%$ & $55 \%$ & $45 \%$ \\
\hline
\end{tabular}

Table 3. Importance of auditing and financial reports

\begin{tabular}{|l|l|l|l|l|l|l|l|}
\hline \multicolumn{2}{|l|}{ Statements } & \multicolumn{2}{l|}{ Auditors } & \multicolumn{3}{l|}{ Bankers } \\
\cline { 3 - 9 } \multicolumn{2}{|l|}{} & Low & Average & High & Low & Average & High \\
\hline 1 & importance of reading auditing report & 7.5 & 11.9 & 80.6 & 26.8 & 23.4 & 49.8 \\
\hline 2 & importance of auditing report & 9.7 & 16.7 & 73.6 & 25.3 & 19.9 & 54.8 \\
\hline 3 & importance of financial statements & 3.0 & 14.5 & 82.5 & 9.2 & 21.8 & 69.0 \\
\hline 4 & importance of company profile & 3.5 & 17.6 & 78.9 & 5.3 & 17.7 & 77.0 \\
\hline 5 & importance of director profile & 8.8 & 17.6 & 73.6 & 5.4 & 15.7 & 78.9 \\
\hline
\end{tabular}


Table 4. Statistical result of fraud and illegal act

\begin{tabular}{|l|l|l|l|l|l|l|l|l|l|l|l|}
\hline \multirow{2}{*}{ Statement } & \multicolumn{4}{l}{ Auditors } & \multicolumn{3}{l}{ Bankers } & \multicolumn{3}{l|}{ Total } & \multicolumn{2}{l|}{} \\
\cline { 2 - 13 } & Mean & Median & St. D & Mean & Median & St. D & Mean & Median & St. D & Z & p \\
\hline 1 & 2.44 & 2 & 1.19 & 4.01 & 4 & 1.14 & $3.276^{*}$ & 3 & 1.401 & -12.29 & 0.000 \\
\hline 2 & 1.56 & 1 & 1.13 & 3.82 & 4 & 1.35 & $2.772^{*}$ & 3 & 1.683 & -14.56 & 0.000 \\
\hline 3 & 2.35 & 2 & 1.06 & 3.54 & 4 & 1.54 & $2.985^{*}$ & 3 & 1.462 & -9.13 & 0.000 \\
\hline 4 & 1.87 & 1 & 1.46 & 3.43 & 4 & 1.45 & $2.7^{*}$ & 3 & 1.649 & -10.21 & 0.000 \\
\hline 5 & 4 & 4 & 0.61 & 3.34 & 4 & 1.45 & $3.645^{*}$ & 4 & 1.180 & -4.77 & 0.000 \\
\hline 6 & 3.28 & 3 & 0.82 & 3.59 & 4 & 1.41 & $3.444^{*}$ & 3 & 1.179 & -5.02 & 0.000 \\
\hline 7 & 2.56 & 2 & 1.09 & 3.6 & 4 & 1.50 & $3.114^{*}$ & 3 & 1.424 & -8.54 & 0.000 \\
\hline 8 & 2.6 & 2 & 1.08 & 3.51 & 4 & 1.47 & $3.086^{*}$ & 3 & 1.381 & -8.22 & 0.000 \\
\hline 9 & 3.93 & 4 & 0.78 & 3.59 & 4 & 1.57 & 3.74 & 4 & 1.273 & -0.31 & 0.759 \\
\hline 10 & 2.6 & 2 & 1.10 & 3.67 & 4 & 1.42 & $3.17^{*}$ & 3 & 1.397 & -8.83 & 0.000 \\
\hline 11 & 4.55 & 5 & 1.08 & 3.59 & 4 & 1.60 & $4.038^{*}$ & 5 & 1.460 & -8.30 & 0.000 \\
\hline 12 & 3.81 & 4 & 0.89 & 3.62 & 4 & 1.56 & 3.71 & 4 & 1.293 & -1.42 & 0.155 \\
\hline 13 & 1.91 & 1 & 1.50 & 3.56 & 4 & 1.54 & $2.788^{*}$ & 3 & 1.726 & -10.45 & 0.000 \\
\hline
\end{tabular}

Note: * Significantly different from Auditors at $\mathrm{p} \leq 0.01$ (two-tail test)

Table 5. percentage of respondent groups

\begin{tabular}{|c|c|c|c|c|c|c|c|c|c|c|}
\hline \multirow{2}{*}{ Statement } & \multicolumn{4}{|c|}{ Auditors } & \multicolumn{6}{c|}{ Bankers } \\
\cline { 2 - 12 } & $1 *$ & 2 & 3 & 4 & 5 & 1 & 2 & 3 & 4 & 5 \\
\hline 1 & 29 & 50 & 2 & 5 & 14 & 2 & 10 & 13 & 32 & 44 \\
\hline 2 & 56 & 16 & 5 & 12 & 11 & 5 & 9 & 14 & 31 & 42 \\
\hline 3 & 20 & 50 & 5 & 15 & 11 & 10 & 10 & 12 & 32 & 37 \\
\hline 4 & 51 & 5 & 11 & 18 & 15 & 9 & 10 & 16 & 39 & 26 \\
\hline 5 & 2 & 2 & 9 & 68 & 18 & 9 & 10 & 19 & 39 & 22 \\
\hline 6 & 4 & 3 & 53 & 21 & 19 & 9 & 8 & 19 & 30 & 33 \\
\hline 7 & 3 & 52 & 8 & 20 & 17 & 11 & 7 & 16 & 27 & 39 \\
\hline 8 & 2 & 51 & 13 & 19 & 15 & 7 & 8 & 18 & 36 & 31 \\
\hline 9 & 3 & 5 & 9 & 65 & 18 & 11 & 7 & 11 & 33 & 39 \\
\hline 10 & 1 & 53 & 9 & 19 & 18 & 9 & 6 & 15 & 33 & 36 \\
\hline 11 & 5 & 4 & 9 & 16 & 67 & 10 & 9 & 14 & 23 & 44 \\
\hline 12 & 4 & 5 & 10 & 67 & 15 & 9 & 7 & 13 & 29 & 42 \\
\hline 13 & 54 & 1 & 7 & 19 & 19 & 11 & 9 & 15 & 25 & 39 \\
\hline
\end{tabular}

*strongly disagree $=1$, disagree $=2$, moderately agree $=3$, agree $=4$, strongly agree $=5$ 
Table 6. Statements

\begin{tabular}{|c|l|}
\hline No & \multirow{2}{*}{ Statement } \\
\cline { 1 - 1 } 1 & Producing the financial statements \\
\hline 2 & Prevention of frauds and errors \\
\hline 3 & Detection of frauds and errors \\
\hline 4 & Conduct of 100 percent examination in audit proceed \\
\hline 5 & Right procedures followed before authenticating financial statements \\
\hline 6 & Certifying accuracy of financial reports \\
\hline 7 & Giving assurance that company is in good financial health \\
\hline 8 & Effectiveness of internal control on audit quality \\
\hline 9 & Maintaining accounting records by the management \\
\hline 10 & Safeguarding the assets of the company \\
\hline 11 & Detecting illegal acts by the management \\
\hline 12 & Reporting all detected frauds and thefts to the relevant authority \\
\hline 13 & Detecting any deliberate distortion of financial information \\
\hline
\end{tabular}

